\title{
Law and Religion. The mystical link
}

\author{
Oana Horhogea \\ “Alexandru Ioan Cuza” University, Iasi, Romania, oana.horhogea@yahoo.com
}

\begin{abstract}
In history, between Law and Religion there existed an important connection because both have their origin in establishing some norms regulating the conduct of man in the society. Thus, if at the beginning, the religious and the legal norms were almost identical, over time these began to differentiate, preserving, however, a latent and permanent connection. In its evolution, law has always represented an assembly of behavioural rules in the social connections, whose main feature is the mandatory feature establish for all its members of a society. By studying religion, we can establish similar rules as the law ones, having as purpose the creation of a manner for preserving peace and understanding between individuals, without family links, rules which had to be complied with by all the participants in a social, economic or religious process.
\end{abstract}

KEYWORDS: evolution, law, norms, religion, rules

\section{Introduction}

Around the year 1500 B.C., in the Middle East, king Thutmose III remained in history as the author of the rules established for the president of the Supreme Court Rekhmire of Egypt, from which it can be observed the clear connection between law and religion.

"Beware in the room of the chief judge; be aware of everything that takes place there. Behold, it is a support for the entire country; (...) Behold, he is not one of those who turn their faces to the clerks and councillors and neither one of those who becomes a brother to the entire world. (...)

You must ensure yourself that you do everything according to the law; that you do everything according to the law (...) in this lies the safety of the clerk: to make things according to the law when analysing what the petitioner says (...) Taking sides is a shameful thing for the Gods. This is the teaching: you will act in the same manner with everybody, you will behold the one who is known to you as if he/she is unknown to you and the one who is close to you (...) in the same manner in which you hold the one who is far from you (...) The clerk who does this will richly prosper in his position. Do not be filled with anger towards a person who does not deserve this, but be filled with anger towards somebody who deserves the fury of anybody" (Danilet 2009, 119).

\section{Law and religion. The mystical connection}

From the oldest times, in all the cultural and religious traditions, the judge was perceived as a person with a very high moral status, endowed with distinct qualities compared to the regular individuals, submitted to some more rigorous constraints compared to others and which must comply with a manner of living and certain more severe and more restrictive behavioural norms than the rest of the community.

Until this stage we can speak of a form making the laws sacred. Their sacred feature derives until this moment from the cult dedicated to the gods, who were considered the source itself of the laws, and from here also the mandatory feature of their application as divine commandments divine, fast est, allowed by the gods.

If the old Egyptian and Babylonian populations confused the law and the religious norms, both being considered the result of the divine will, the Romans managed to delineate the law norms regarding the name of jus and the religious ones with the term fas.

The delineation between jus and fas took place after the establishment of the Republic, in 509 B.C. As immediate consequence, the Pontifex Maximus, who was the leader of the pontiff's college, named for life among his colleagues and endowed with the religious prerogatives of the former kinds, lost a great part of his tasks.

For the Romans, the law was considered "the art of good and of equity", having a sense both moral, which related to religion, as well as judicial. Domitius Ulpianus, known in history with the 
name of Ulpian, lived in ancient Rome during the period 170-223 A.D. Being considered one of the highest judicial authorities in that time, he identified the following basic principles of the law:

- To live in an honest manner,

- Not to harm another person,

- Give everybody what belongs to him/her.

"Juris praecepta sunt haec: honeste vivere, alteram non laedere, suum cuique tribuere." The law in the Antiquity comprised three parts: praescriptio, rogatio and sanctio. In praescriptio it was written down the name of the magistrate who drafted the law, the name of the commissions who voted the law, the date and place of voting. Rogatio comprised the text itself of the law, divided in chapters and paragraphs. Sanctio comprised the punishment which interfered in case of failing to comply with the dispositions from the rogatio. According to the nature of the sanction, the laws were classified in three categories:

- leges perfectae;

- leges imperfectae;

- leges minus quam perfectae.

The leges perfectae were those laws for whom the sanction foresaw that any document concluded with the breach of the dispositions from the rogatio was going to be annulled.

The leges minus quam perfectae were those laws which contained certain dispositions, based on which the document drafted by breaching the dispositions from the rogatio remained valid, but the author was going to be punished, usually, with a fine.

The leges imperfectae did not foresee any sanction for breaching the dispositions from the rogatio. Such as it can be observed, for the Romans, the laws comprised a religious aspect both as linguistic expression as well as with regard to their content.

The solemn agreements, named also formal agreements, represent the oldest category of agreements. In this category of agreements, it is included: religious agreements, agreements in the oral form, authentic agreements, agreements in a written from (litteris) (Molcut 2011, 162).

The agreement in the religious form (sponsio religiosa) is the oldest Roman agreement made up of a question and an answer, at the end this being concluded by repeating a religious oath.

The iusiurandum liberti agreement includes also a religious form, it having two successive oaths, the slave undertaking, through this, the obligation to provide the services to the master or to provide qualified services.

Later, in the Roman law, (...) the parties stated in front of the magistrate, within formalistic terms, the claims. These claims were underlined through a religious oath. In addition to the oath, the parties were obligated to make a bet and to deposit with the magistral pontiffs the money in the amount of 50 or 500 asses, whether the value of the claim's object was less or more than 1,000 asses. The asse was the old copper Roman coin. The one who lost the trial, lost also the money submitted with the title of bet (Ciucă 1998, 63).

Plato understood also that the truth is always represented by the good and beautiful. In the domain of the intelligible, above everything, is the idea of Good which, once seen, must be conceived as the reason for all that is law and beautiful (Platon, 2005, 107).

Plato's school of philosophy and teachings were dedicated by gaining the truth. All the dialogues from his works have the same purpose, that of reaching the truth.

If in The republic, Plato describes a city in which the laws are not necessary because the virtue belongs to each individual and he considers it enough in the human relations, in the Laws book, Plato renounces the ruling of the philosophers, this being replaced with the rule of the law. From here it is observed the necessity to establish some regulations under the judicial norms' form.

Between law and religion several types of relations can be distinguished. For example, the law and religion are conceptually related. Both subjects are based on the same fundamental concepts regarding the nature of the existence and of the order, of the person and of the 
community, of the knowledge and of the truth. Both the law and religion conceive in an analogue manner the sin and the crime, the convention and the agreement, the salvation and the rehabilitation, the lawfulness and the justice, which inevitably combine in the mind of the legislator, judge or that of the juror.

Both the law and religion are based one on the concepts of the other in order to form their own doctrines. The judicial doctrine of the punishment according to the crime is based on the theological doctrine of the Purgatory and of the redemption (...) Both developed hermeneutic analogous methods, manners of interpreting doctrinarian text. Both developed logical methods, manners of deducing precepts from principles, to rational based on the analogy and the precedent. Both developed ethical methods, manners of translating the values and convictions of the most profound in the habits linked to a mandatory or recommended behaviour. Both developed judicial and rhetorical methods, manners of employing and presenting the arguments and information. Both developed methods of bringing proof and judging the litigations. Both developed methods of organising, systemising and teaching the necessary educational disciplines (...)

The law and religion are related from the professional point of view. In many early communities, and in certain groups also today, practicing law and religion is carried out by the same persons. With judicial and sacerdotal responsibilities is invested either the Church, or a person, chief of tribe, oracle, pontiff or rabbi. Even when these two professions are differentiated, they remain closely related. The professions are similar also in terms of form. Both require a profound education of the doctrine and maintain very high admission standards. Both developed professional ethical codes and authority internal structures in order to strengthen the position. Both are searching to promote collaboration, collegiality and the team spirit. Moreover, the professions function in parallel. There exist affinities between the mediation of the lawyer and the intermediation of the priest, between the delivery of the verdict by the Court and the arbitrage of the consistorial (...) Theoretically, both professions serve the society. Both try to be examples of the ideals of the calling and of the community. These, as in other forms of interaction, have brought the legal and religious domains and in reciprocal dependency. (Witte, 1995, 51 and the following)

\section{Conclusions}

The genesis of the law is linked to the historical appearance of the state. At the same time with the human evolution, the people living in small nomadic groups gradually approached another lifestyle. Religion, which was a part of their life, became a mean of insuring the social, political, judicial and economic stability through rules.

The slow passing from one historical period to another the economic, social, political, judicial and religious managed to modernise the society and, in the end, determined the necessity to conceive a set of norms through which the human conduct was being regulated.

As we can observe both the law as well as the religion had in the centre the human being, and all the norms created are linked with it. These were two institutions which had at the foundation the conviction that for each individual the rules must be complied with no matter if they are of divine nature or created by a human. Both had as purpose the protection of man and the creation of instruments through which his positive actions were delimitated from his negative ones.

The mystic link which appears from the feeling that the conduct rules represent the mandatory feature of some norms pre-established both by the Law as well as by Religion through the "DIVIN ORIGIN."

"Science without religion is limp, religion without science is blind"

(Albert Einstein) 


\section{References}

Ciucă, Valerius. 1998. Lectii de Drept roman. Iasi: Polirom Publishing House.

Dănileț,Cristi. 2009. (traducere and adaptare). Standardele de la Bangalore privind conduita judiciara. UNODC.

Molcuț, Emil. 2011. Legea privata romana. Bucharest: Universul Juridic Publishing House.

Platon. 2005. Republica. Bucharest: Antet Revolution Publishing House.

Witte, John Jr. 1995. Law, Religion and World Peace, elaborat pentru The Tami Steinmetz, Center for Peace Research, Tel Aviv University. 